УДК 37.043.2

\title{
СУБЕКТНО-ОРИЕНТИРОВАННЫЙ ПОДХОД К ВОСПИТАНИЮ ТВОРЧЕСКОЙ ИНДИВИДУАЛЬНОСТИ СТУДЕНТА В КОНТЕКСТЕ ПОДГОТОВКИ СПЕЦИАЛИСТА БУДУЩЕГО
}

Горшкова Валентина Владимировна д.п.н., профессор Санкт-Петербургский Гуманитарный университет профсоюзов Богданов Иван Викторович к.П.н., доцент Севоро-Западный институт (филиал) АНО ВО Московский гуманитарноэкономический университет

Аннотация: В статье заявлены условия реализации субектноориентированного подхода к воспитанию творческой индивидуальности студента в контексте подготовки специалиста будущего; раскрыто влияние идеи импрессинга на развитие личности студента; показана готовность системы высшего образования к подготовке современного специалистапрофессионала в режиме его развития как творческого субъекта.

Ключевые слова: Субектно-ориентированный подход; воспитание творческой индивидуальности; теория импрессинга, креативный потенциал студента; подготовка современного специалиста.

\section{A SUBJECT-ORIENTED APPROACH TO THE EDUCATION OF A STUDENT'S CREATIVE PERSONALITYIN THE CONTEXT OF TRAINING A SPECIALIST OF THE FUTURE}

\section{Gorshkova Valentina Vladimirovna Bogdanov Ivan Viktorovich}

\begin{abstract}
The article states the conditions for the implementation of a subject-oriented approach to the education of a student's creative personality in the context of training a specialist of the future; reveals the influence of the idea of the
\end{abstract}


concept of impressing on the development of a student's personality; shows the readiness of the higher education system to train a modern specialist-professional in the mode of his development as a creative subject.

Key words: Subject-oriented approach; education of creative individuality; impressing theory, creative potential of the student; training of a modern specialist.

Реализуя идею не только подготовки специалиста, но и становления студента как полноценного человека с учетом развития его всесторонних способностей, мы опирались на достижения философско- психологических наук о свойствах психики развивающегося человека как субъекта, его интеллекта, поведения, отношений и влияния на него социального окружения [1]. В контексте реализации идеи развития необходимо учитывать, что в значительной степени социальность студента как человека формирует его субъектную уникальность, способствует окультуренности его биологического начала, способствует умению выражать собственную мысль в вербальной и невербальной форме, то есть умению мыслить и говорить.

Данная публикация представлена на основании анализа некоторых направлений реализации культуроцентриской модели воспитания в условиях образовательного процесса Санкт-Петербургского Гуманитарного университета профсоюзов [2].

В данном контексте реализация субъектно-ориентируемого (субъектноиндивидуального) подхода, как считают современные исследователи (В.И. Слободчиков, В.М. Розин, В.В. Горшкова, В.П. Зинченко и т.д.), должен начинаться в детстве, юности и активно, корректно активизироваться в течении всей жизнедеятельности человека.

Выдвигая амбициозную гипотезу о развитии творческой индивидуальности каждого студента при актуализации его креативного потенциала [3] в условиях университетского пространства актуализировался культурносоциальный стимул под названием «импрессинг». Импрессинг - это различные (могут быть любые) впечатления, воспринятые в чувствительные периоды формирования личности и наложившие отпечаток на всё последующее развитие. Импрессингом может стать что-то услышанное (слово, музыка, история, факт биографии и т.д.), увиденное (яркое, драматическое, возбуждающее и т.д.) и воспринятое в определенном смысле как потрясение души. В целом, явление импрессинга означает существование особо чувствительных периодов избирательной эмоциональной и 
интеллектуальной восприимчивости к внешнем впечатлениям, которые надолго могут определить всё последующее поведения, основные ценностные критерии, характер отношений к окружающим, этические нормативы, подсознательные решения и многое другое. Так, импрессирующие действия на развивающегося человека в позиции субъекта, а также возбуждающее творческую энергию студента оказывают университетское окружение, включающее некоторых сокурсников как интересных людей и отдельных преподавателей, отличающихся своей незаурядностью и способных оставить «неизгладимый след» в жизни обучающихся; литературно-поэтические, музыкальные, научно-интеллектуальные встречи с выдающимися представителями культуры политики и общественной жизни; активно мотивированное участие студентов в предлагаемых различного направления проектах; присутствие в оригинально организованном и оформленном университетском пространстве; создание событийной общности в условиях воспитательной среды ВУЗа и т.д.

В предлагаемых обстоятельствах необходимо создавать условия, при которых у студентов будет воспитываться чувство осознанности значения своего творческого труда уже в стенах ВУЗа, пусть пока недостригшего ожидаемых результатов и не признанного окружающими. Однако, у развивающейся творческой индивидуальности свои ценности в сравнение с не столь творчески напряженными и менее целеустремлёнными окружающими людьми.

Известно, что ценностные параметры творчески работающих индивидуальностей не соответствуют «норме» и для достаточного количество людей могут быть непонятными, неприемлемыми и даже раздражающими для представителей нормы. Однако, совершенно ясно, что психику высоко талантливых людей никак нельзя считать аномалией, а скорее наоборот [4]. Для таких личностей свойственно внутреннее напряжение, поскольку они воспринимает цель жизни и «рефлекс цели» (В.П. Эфроимсон) как нечто такое, по сравнению с чем все остальное остается второстепенным. В деятельности творческого человека очевидное значение имеет сосредоточенность, концентрированность, молниеносное переключение от одной деятельности на другую, внутренняя направленность на главное, повышенная интеллектуальная напряжённость, эмоциональная интенсивность («интенсивность - это всё» - Оноре де Бальзак), целенаправленная мобилизованность, духовное напряжённость мышления. 
Вместе с тем, критичность мышления и высокий уровень рефлексии выражается в исключительной направленности анализа на себя (самоанализа), что остерегает от опасности проявления ничем несдерживаемых аффектов самоутверждения.

Возникает вопрос: насколько готова система высшего образования к подготовке современного специалиста-профессионала в режиме его развития как творческого субъекта? На сегодняшний день констатируется факт, что введения широкого среднего образования, демократизация контингентов, поступающих в ВУЗы еще, не обеспечивает страну неизчерпающими фондами потенциальных талантов, а для успешной конкуренции не разработана и не введена эквивалентная система отбора и развития талантливой молодёжи. Известно, что уже достаточно давно сложилось реальное отставание в научной сфере и в технологиях во многих областях, где требуется приложение интеллектуальных усилий и в которых необходимы свобода мысли и свобода творчества, поэтому задачи высшего образования не ограничиваются лишь индивидуализацией образовательного процесса и усовершенствованием его рецептурологии.

Справедливости ради следует заметить, что в стране пока не создана соответствующая система подготовки специалистов профессиональнопедагогического профиля для работы с особо творческими, неординарными, ярко индивидуальными (уникальными) обучающимися, что представляется не менее сложным (если не более), чем работа с детьми и молодёжью, требующими особого педагогического внимания («группа риска»). Кризисная ситуация, сложившаяся в высшей школе связана с отбором и подготовкой талантливой молодёжи, необходимой для её профессионального образования в зоне опережающего творческого развития, для поиска ответов на вопросы, которые уже поставила жизнь.

Драматизм и трудности педагогов (воспитателей) скорее всего заключаются в том, что им не известны механизмы импрессинга, которые могут снизить риск случайности в обучении и воспитании, а также не раскрыта серия индивидуальных импрессингов, поскольку научные обоснования о теории импрессинга пока не изучены основательно. Однако, вместе с тем понятно, что без равноценностного общения педагога со своими обучающимися и воспитанниками не могут быть правильно подобраны необходимые способы (технологии), открывающие потенциальные возможности личности, ту сложную развивающуюся «педагогическую 
симфонию», которая построена на импрессинге, то есть на формировании ценностных ориентиров, пробуждении воли, настойчивости, целеустремлённости, самоотверженности, альтруизма, чувства долга. Сегодня эволюционная сфера развития человека разоблачает значительный вред, который нивелируется массой информационной продукции, но она же и вскрывает огромные потенциальные возможности участников образовательного процесса.

\section{Список литературы}

1. Розин В.М. Образование в условиях модернизации и неопределенности / В.М. Розина. - М.: ЛИБРОКОМ, 2013. - 80 с.

2. Запесоцкий А.С. Культуроцентриская модель высшего образования / науч. ред. А.С Запесоцкий. - СПб.: СПб ГУП, 2010. - 292 с.

3. Горшкова В.В. Филосовско-психологические основания субъектной педагогике в условиях высшей школы // Педагогика. - № 2. - 2019. - С. 14-23.

4. Эфроимсон В.П. Гениальность и генетика / В.П. Эфроимсон. - М: Русский мир. - 1988. - 544 с. 